\title{
Progressive Unionist Party Conference: October 12, 1995
}

\author{
William Smith, \\ Prison Spokesperson
}

Last year we reported that Sir Patrick Mayhew had announced he was to introduce $50 \%$ remission for all prisoners in NI. At the time, we felt that this was not enough. We still feel that way; however, we did accept that it was a first step in the right direction, with the expectation that there would be more movement as the peace process unravelled.

He also stated that, due to the different atmosphere pertaining in the country, the 'risk factor' would be taken into consideration when life-sentence prisoners were having their sentences reviewed. Sadly, I have to report to the conference, that one year on, two years into the Loyalists ceasefire, there has been no further movement whatsoever on the issue of prisoners, and also no movement whatsoever on the reviews of life sentence prisoners.

Since last year, we have endeavoured to get movement on prisoners. We have had numerous meetings on prisoners, meetings with NIO. Officials, Prison Officials, Civil Servants, John Wheeler, Michael Ancram, and Patrick Mayhew. Despite all these meetings, the government has not shown any willingness to change their position on prisoners.

I must take this opportunity to clarify our position paper on prisoners because it was not, as some would have you believe, a demand to open up the gates and let everyone walk out. Our submission to the government contained 30 pages of measured, constructive, and achievable steps to bring about the eventual release of prisoners. Included in that submission were confidence-building measures such as increased paroles; extended time of paroles; reduction in qualifying criteria for paroles; greater flexibility in paroles; greater access to education, training schemes, and job programmes; access and recognition of LPWA on a par with other Welfare Organisations, etc., etc.

I regretfully state that the government did not help or contribute to any of these points. In the event of Canary Wharf, Manchester, Innsbruck, and Killyhevlin when the Loyalists ceasefire was coming under tremendous strain and we were looking for help, support, for even a tiny movement on prisons and other issues to shore up the Loyalist ceasefire, the government gave nothing they gave nothing but patronising pats on the back.

Eight weeks ago, a PUP delegation met with Sir Patrick Mayhew and expressed concerns at the lack of movement on prison issues. At his sugges- 
tion, a shopping list was prepared and sent to him which included phased released, increased remission, review of life-sentence prisoners, equity in the parole system between men and women, extensions of compassionate home leave, and - wait for it! - the ending of the practice of handcuffing prisoners on hospital appointments. Yes, two years into a Loyalist ceasefire and our prisoners are still being handcuffed while going to hospital for treatment. Only recently, one particular prisoner was handcuffed to the hospital bed.

Eight weeks later, we have not even received a reply to any of these points. Two weeks ago, representatives of the UDA prisoners in Long Kesh announced through the media that the UDA/UFF prisoners had told them they had removed their support from the peace process. The sentiments they expressed were shared by all Loyalists both inside and outside the prison.

- The continued violence by Republicans.

- The lack of progress with the political process.

- The failure of the government to recognise the efforts of the Loyalist leadership in sustaining the peace.

Last Monday, a terrible burden was placed on W F/RHC prisoners as the media and the world looked towards them to see what their position was in the peace process. It was an unique occasion as a delegation of 14 was allowed inside the prison were they met a group of 30 prisoners in the prison gym. As we sat around a make-shift conference table, prisoners exchanged their views with their colleagues in the delegation. For three and half hours, the discussion varied, covering all aspects of the current position. The acoustics in the building were not ideal, and as the meeting moved into its final stage, two dull thuds, 15 minutes apart, were heard. As news of the Lisburn bombs filtered through, we all felt anger, disgust, and bewilderment at this deliberate attempt at mass murder of men, women, and children by violent Republicans.

At that point, it would have been so easy to allow emotions to run rampant; it would have been understandable if prisoners had lost faith in the peace process. But they did not. They continued the meeting with determination, courage, and restraint. They did not allow the I.R.A. to deflect or to sabotage the purpose of the meeting. They asked us to relay their sympathies for those injured, and now sadly, to the family of Warrant Officer, James Bradwell, who died yesterday as a result of the Lisburn bombs.

We left Long Kesh on Monday with clear resolve from the prisoners. They said that, while there was a ray of light, a glimmer of hope, left in the peace process, for the sake of the people of NI, for the sake of the 'future of the NI,' we should continue to strive to make the process work. I wish you all could have 
been there to hear their unselfishness and comforting attitude. You would have been proud of them.

There are a number of elements that contribute to the success of the Loyalist ceasefire. The leadership of the Loyalist paramilitaries on the outside showed great courage and foresight, not only in calling the ceasefire, but in maintaining that ceasefire for the past two years through the most difficult times.

The PUP gave political analysis and direction and articulated the new and real voice of Loyalisim. The other element of course is the people we have just been talking about. Throughout the whole two years, our prisoners have never wavered in their support for the leadership on the outside and the PUP Whenever we needed a shoulder to lean on, they have been there. Whenever the ceasefire has been under stress, they have been there to prop it up and lend support. Their contribution to the peace process is unquantifiable.

When we call for the phased release of prisoners, it is not just for the purpose of getting people out. The confidence-building measures leading to release cement the process, consolidate the process, and conclude the process. We hope that the conference will support the continued efforts to secure the ultimate release of all Loyalist Prisoners of War. 